studie 



\title{
Hereze v listech rané Jednoty bratrské
}

\author{
Michaela Vašíčková
}

\begin{abstract}
Heresy in Letters by Early Unity of the Brethren

The study depicts heresy as a type of social deviance in letters of Akty Jednoty bratrské, published in a two-volume collection by Jaroslav Bidlo in the first half of the 20th century. As a popular tool to discredit an opponent, heresy plays a vital role in religious polemics in the 15 th century. The brethren - members of a new "sect" - face this aspersion in countless texts. Authors of the chosen letters carefully build and adapt their image in front of their adversaries as well as the society as a whole. They have to defend themselves against verbal attacks and accusations and, first of all, to justify their radical religious approach. Except for texts by the Unity of the Brethren, the study also deals with letters by their Utraquist opponents, such as Prague university masters or the archbishop Jan Rokycana. Hand in hand with the literary analysis, the approaches of sociolinguistics and pragmatics reveal the basic communication strategies of the brethren; using the Scripture, the authors try to back up their approach to faith, while they are forced to reflect the plain reality, attempting to ensure their own safe existence without persecution. As a result, the approach demonstrates an interesting (yet understandable) duality, mingling theological issues with the prosaic reality of the very end of the Czech Middle Ages.
\end{abstract}

\section{KEYWORDS}

Unity of the Brethren; heresy; social deviance; communication strategies; Hussitism.

\section{KLÍčovÁ SLOVA}

Jednota bratrská; hereze; sociální deviace; komunikační strategie; husitství.

Rok 1451 představuje pro náboženské dějiny českých zemí zásadní milník: „papež Mikuláš V. požadoval, aby se husité vzdali kompaktát a bezvýhradně se podřídili latinské církvi; ujednání, k nimž došlo během basilejského koncilu, již 
koneckonců pozbyla platnosti“ (FUDGE 2017: 278). ${ }^{1}$ Výrazná neochota, ba přímo odmítnutí českých a moravských utrakvistů vzdát se výsad, kterých díky sáhodlouhým vyjednáváním dosáhli, nepřestávala budit údiv napříč Evropou. Pověsti kacířů, která provázela (nejen) delegáty z Českého království již ve 30. letech 15. století, se obyvatelé českých zemí neměli jen tak zbavit. Obvinění z kacířství, resp. hereze, bylo poměrně častým, avšak proměňujícím se jevem, který se neomezoval jen na střední Evropu.

$S$ herezí se věříí mohli setkat již v době počátků křestanství - kořeny tohoto konceptu sahají až do židovské tradice. Etymologicky termín vychází z řeckého výrazu hairesis s původním významem ,záměrná volba' nebo ,sekta'. Jak uvádí Ian Hunter, John Christian Laursen a Cary J. Nederman, lze kacířství (herezi) „pojmout v širším či užším smyslu. Podle nejobecnější definice jsou vůči sobě heretická různá náboženství. V užším smyslu se jedná pouze o rozdílné názory mezi jedinci, kteří se řadí $\mathrm{k}$ téže víře“ (HUNTER - LAURSEN - NEDERMAN 2005: 1). ${ }^{2}$ Jennifer Deane v této souvislosti upozorňuje na binární podstatu hereze a ortodoxie (DEANE 2011: 2), které nutně stojí proti sobě a v polemických sporech pomáhají utvářet identitu autora, adresáta či dalších osob. Z tohoto důvodu Deane označuje kacířství jako „umělou kategorii vytvořenou autoritami“ (IBID.). ${ }^{3}$ Základ k těmto jednoznačně kontrastním pozicím, které zároveň existují ve vzájemné závislosti, můžeme nalézt i v Prvním listu Korintským, konkrétně těchto verších: „Především se doslýchám, že když se scházíte v církvi, máte mezi sebou roztržky, a skoro tomu věřím. Musí totiž mezi vámi být i rozdělení, aby se ukázalo, kteří z vás jsou spolehlivi“ (1 Kor 18-19).

Hereze ovšem není zdaleka jediným nástrojem či konceptem umožňujícím nakreslit ostrou linku mezi žádoucím a naopak odsouzeníhodným jednáním. Hovořit o herezi by totiž nebylo možné, neexistoval-li by ve společnosti obecně přijímaný pomyslný soubor norem, podle nichž lze „posuzovat chování a rozhodovat, zda jej můžeme považovat za správné a odpovídající postoji většinové společnosti“ (ROGGE 2016: 9). ${ }^{4}$ Odpovědné osoby se pak starají o přeměnu „nekonkrétních hodnot v konkrétní pravidla chování nebo způsob jednání, na jejichž základě můžeme rozlišovat mezi akceptovaným a neodpovídajícím chováním“ (IBID.). Tyto osoby musejí disponovat potřebnou sociální mocí - právě ona jim umožňuje normy v konkrétní podobě propagovat a protežovat. $\mathrm{Z}$ pohledu

\footnotetext{
1) Přel. M.V.

2) Přel. M.V.

3) Přel. M.V.

4) Přel. M. V.
} 
sociologie existují dva základní procesy, které jsou většinové společnosti vlastní (bez ohledu na to, zda jde o společnost středověkou, novověkou nebo moderní) a které pomáhají udržovat tzv. sociální kontrolu nad nežádoucími vlivy, jako je třeba právě hereze. Prvním z těchto procesů je „internalizace skupinových norem, [...] díky které lidé vědí, co se od nich očekává, a touží po tom, aby očekávání dostáli“ (CLINARD - MEIER 2008: 28). ${ }^{5}$ Druhý proces má podobu „vnějších tlaků, konkrétně sankcí z vnějšku, pro případ očekávaného nebo již uskutečňovaného nesouladu jedince s normami“ (IBID.). At' už jde o nonkonformitu s jakýmikoli normami (kulturními, náboženskými, obecně společenskými...), jedinec, který se jí dopustí, je považován za „deviantního“ (ROGGE 2016: 11). Zasahuje se tak do společenského postavení člověka, nebot' je více než žádoucí, aby o tomto označení věděla aspoň část veřejnosti. $V$ případě hereze lze předpokládat, že o označení určité osoby (případně celého uskupení nebo dokonce jiného vyznání) touto nálepkou by měli vědět lidé, které tato osoba může potenciálně ovlivnit či je již ovlivnila.

Zatímco v sekularizované společnosti dochází k oficiálnímu ,přidělení statusu devianta (ve smyslu ,významně se odchylující od normy') především na základě soudního procesu, religiózně zaměřená společnost dává tuto moc církvi. K označení osoby coby heretika či ,pouze člověka s názory, jichž se mají ostatní vyvarovat, mohl kněz nebo jiná církevní autorita využít dobu mše, tedy přímo kázání, případně - s ohledem na adresáta sdělení - listy, traktáty a podobné typy textu. Reflexi deviantního chování můžeme nalézt např. i v kronikách, vyšetřovacích záznamech či cestopisech (IBID.: 14-15).

Při zkoumání dobových textů, které operují s pojmem hereze a používají jej jako více či méně účinnou nálepku (label), je nutné brát zřetel na to, že toto označení - bez ohledu na status pisatele - náleží samotnému textu, tj. nevychází automaticky z mimotextové reality a nemusí zcela odpovídat názoru tehdejší majoritní společnosti. Navzdory na první pohled jasnému vydělení heretického chování a heretických postojů nemusí tato nálepka obsahovat závažnost, kterou bychom jí přidělili např. na základě výše citovaného Prvního listu Korintským. Jak upozorňuje Hunter, Laursen a Nederman, v době reformace se totiž z hereze stává „všeobecný termín vyjadřující opovržení vioči náboženskému protivníkovi“. $Z$ hereze se postupem času „stalo přízvisko používané k označení odpadlictví nebo nějaké náboženské roztržky“ (HUNTER - LAURSEN - NEDERMAN 2005: 3-4). V českém prostředí ovšem podobnou tendenci spatřujeme již o něco

5) Přel. M. V. 
dřive - právě v polemických textech z 15. století. Herezi navíc nelze např́ič dějinami definovat tak snadno jako jiné deviace, u nichž se můžeme opřít např̀. o legislativní definici.

Působivou ukázkou práce s konceptem hereze a nábožensko-společenské deviace je list pražských utrakvistických mistrů adresovaný Jednotě. Spadá do třetí skupiny textů druhého svazku Aktů Jednoty bratrské a vznikl podle odhadu editora Jaroslava Bidla snad roku 1474 (BIDLO 1923: 52). Obvinění z hereze se v listu pražských mistrů zakládá na neoprávněném vykládání Písma, nerespektování autorit, jež uznává církev, a přílišné důvěře ve vlastní interpretaci božích nařízení. Jednota bratrská se tedy z pohledu pisatelů neřídí ustanoveným společenským řádem a jednoznačně odpovídá charakteristice kacířského uskupení:

„Item, ještě jsme znamenali, že svrchu psaný kněz Michal se vší svou rotou přiliš všetečně svým vtipům a rozumům velmi věří a pokud nejvíc můž rozuměti, potud písma svatá vykládá a k svým bludom je přilepuje a doktory svaté zamítá. Nechce věřiti doktorom svatým, ano Duch svatý mluví skrze doktory svaté staré, jež sou byli naplněni milostí jeho, [protož] již netřeba falešným vtipom svým věřiti a nepřestupovati cíle a mezí, kteréž sou staří otcové náši, apoštolé a jiní světí doktorové položili, neb to jest rada Ducha Svatého stará a všem lidem má býti vzáctná a k spasení dostatečná“ (Psaní mistrův Pražských in AJB 2 1923: 124).

Zmiňovaný kněz Michal v listu do značné míry zastupuje celou Jednotu, kritika cílená na něj se tedy dá vztáhnout na všechny představitele Jednoty. Deviace zde spočívá $\mathrm{v}$ př́lišném spoléhání se na vlastní výklad Písma a vlastní rozum. Narážka na nedostatečnou schopnost porozumění sofistikované látce - „pokud nejvíc může rozuměti“ - je vlastně okrajová; pisatel zdůrazňuje Michalovu svévolnost a dobrovolné odmítání podřídit se autoritám. Dokazují to výrazy jako všetečný, vtipy, rozumy, zamítat. Klíčovým pojmem zde jsou bludy, jeden z nejčastěji používaných výrazů při snaze diskreditovat protivníka v náboženské polemice. Odkazování $\mathrm{k}$ bludům není na sklonku středověku výjimečné i z toho důvodu, že se ve vernakulárních literaturách (tedy nejen v té česky psané) setkáváme stále častěji s pokusy o překlad Písma. Drahomír Suchánek a Václav Drška ovšem v této souvislosti upozorňují na nebezpečí nevyhovující, či dokonce nebezpečné interpretace určitých pasáží, čehož si byl klérus vědom. Proto se nelze divit, že i přes rozvoj knihtisku byla církev vi̊či těmto snahám obezřetná a z vlastního výkladu Bible se mohl stát argument k diskreditaci protivníka. Zbývá dodat, že ze stejného důvodu římská církev na samém začátku 16. století ustanovila dohled nad věroučnými texty (SUCHÁNEK - DRŠKA 2013: 319). 
Kněz Michal navíc podle autora textu nechce následovat pravé, ověřené učení teologů, kteří zprostředkovávají slova samotného Ducha svatého. Pisatel tedy pracuje se základním atributem heretika - „neposlušností vycházející z pýchy a svévolným zavržením ortodoxie poté, co kacír dostal šanci své postoje změnit“ (DEANE 2011: 4). Implikuje se tak, že kněz Michal by se mohl navrátit k pravému učení, ovšem vlastní pýcha mu v tom zabraňuje. $\mathrm{V}$ tomtéž odstavci rovněž spatřujeme akcentaci zavedeného a tradičního, které se zakládá na Duchu svatém, v opozici k Michalově „rotě“ (viz „cíle a meze, kteréž sou staří otcové náši, apoštolé a jiní světí doktorové položili“ nebo „rada Ducha svatého starác).

Pojem rota se v listu pražských mistrů neobjevuje náhodou; na více místech označuje uskupení lidí, které kolem sebe měl shromáždit právě kněz Michal. Rota ve staročeštině označovala „družinu“ či „skupinu“, ale také „sektu“, „stranu“ (viz „Rota“ in VOKABULÁŘ). Dá se proto předpokládat, že i v tomto listu pisatel pracoval s určitým zabarvením uvedeného slova. Dokazují to fráze jako „[kněz Michal] zapálen se vší svou rotou“ (Psaní mistrův Pražských in AJB 2 1923: 122), „novou rotu sbírá“ (IBID.), „kněz Michal s svou rotou prŕíliš vysoce smyslí“ (IBID.: 124). Za povšimnutí stojí jistě i skutečnost, že z roty se v textu stává homogenní masa lidí, žádné individuum z ní nevystupuje, jako jedinec $s$ vlastní vưlí zde figuruje pouze kněz Michal. O to více tak autor akcentuje, jak je důležité omezit vliv tohoto jedince s výrazně deviantním chováním. Není náhoda, že autor textu využívá koncept homogenity skupiny - jde o běžný nástroj, který při kritice či polemice pomáhá vytvořit jednodušší obraz protivníka. Používá se, jak potvrzuje Deane, i v př́ípadě, že se ve skutečnosti nejedná o jednotnou komunitu s jednotným názorem (DEANE 2011: 6).

Pisatel považuje za důležité vykreslit osobu kněze Michala poměrně podrobně a poznámky týkající se jeho charakteru či dehonestující výtky nacházíme v listu poměrně hojně. Kromě již uvedené svévolnosti zde hrají roli vlastnosti jako hněv („hněvem přilišným jsa zapálen“ /Psaní mistrův Pražských in AJB 2 1923: 122/), zchytralost a tvrdohlavost („ve dne i v noci vtipy a rozumy divné zbírá“/IBID./), špatný vliv na okolí („zbouřil světské lidi“/IBID./) a tak zamezování lidem v dosažení spásy („divné bludy mezi ně uvodí“/IBID./). Navzdory značnému důrazu na postavu Michala $v$ listu autor hovoří o protistraně místy i s použitím 3. osoby plurálu, popisuje tak tedy i Michalovy následovníky. Stále však platí, že v listu patrně není účelem soustředit se na jednotlivé osoby (vyjma Michala), ale vykreslit Michala jako hlavního strůjce a jeho následovníky coby jednotnou skupinu. Použití 3. osoby plurálu zde navíc autorovi umožňuje 
postavit do přímé opozice svou stranu, tj. pražské mistry, a reflektovat tak jejich skutečné setkání s ideovými protivníky:

„[C]hytrý diábel chtěl by tu cestu zkaziti a nemoha tomu nic učiniti, přijal jest k sobě pomocníky, kněze Michala s jeho rotou, aby oni jemu s ctnostným životem svým pomáhali a z cesty pravé, apoštolské, kterouž nynější kněží lidu káží a oznamují, kněz Michal svrchu psaný se vším svým tovaryšstvem chytrými vtipy skrze falešná učení hledí lid boží z té cesty pravé vyraziti. V pravé pravdě to pravíme, že když sme s nimi oustně rozmlouvali a potom čtouce jich traktátec, řeči jich s pilností sme rozjímali, poznali sme, že sou velmi v rozumu nakažení a diábel hledí skrze ně v lid veliké zlé uvesti i pochybování u víře“ (IBID.: 123).

V první řadě se zde opět akcentuje chytrost (zde ve smyslu zchytralost, vypočitavost); je spojována s myšlením a učením Bratří, ale též figuruje jako adjektivum charakterizující d'ábla. Jasně antiteticky působí protiklad falešnosti (falešná učení) a pravdy. Pravda bývá při obraně náboženských stanovisek použivána jako jedna ze základních charakteristik následovníků Ježíše Krista a jeho učení, a v tomto odstavci je asociována jak se ,správnou cestou podle Písma („hledí lid boží z té cesty pravé vyraziti"), tak s mistry samotnými, jež pisatel zastupuje. Mistři podle autora hovoří „v pravé pravdě“ (dvě slova z totožného základu), v jiném odstavci je zase použita téměř stejná formulace „v pravé pravdě to pravíme“, zde navíc v paralele k frázi „víra pravá křestanská“ (IBID.: 124-125). Pisatel též klade důraz na skutečnost, že o myšlenkách a tvrzeních protistrany již dříve „s pilností [...] rozjímali“ (IBID.: 124) a teprve poté došli k závěru, že Bratři jsou „nakažení;; vlastně se zde stávají pouhým nástrojem d'ábla, šiřiteli pomyslné nákazy, která má již sama o sobě veskrze negativní konotace.

Závažný problém - úzce související se svévolností - v tomto listu představuje Michalovo nerespektování autorit, jichž by si podle slov mistrů měli všichni křestané vážit, a jednoznačné překročení hranic v přístupu k božímu slovu. Autor zmiňuje jeho nekompetentnost: „pokud nejvíc můž rozuměti, potud písma svatá vykládá a k svým bludom je přilepuje a doktory svaté zamítá“ (IBID.). Skutečnost, že vykládání Písma Michalovi nepřísluší, zde ilustruje profánní výraz přilepovat. Společenská deviace - v tomto kontextu nerespektování autorit a odmítání tradice - je jasně znázorněna v tomto úryvku: „netřeba falešným vtipom svým věřiti a nepřestupovati cíle a mezí, kteréž sou staří otcové náši, apoštolé i jiní světí doktorové položili, neb to jest rada Ducha Svatého stará a všem lidem má býti vzáctná a k spasení dostatečná“ (IBID.). Kněz Michal tedy podle dikce textu odmítá akceptovat autority, jimž mají všichni důvěřovat a jež jsou 
prověřené léty. Pisatel zde s jasným záměrem zdůraznit dlouhotrvající tradici opakovaně používá adjektivum starý v pozitivním významu. Pozitivní konotaci též lze vidět v paralele svatí doktorové a Duch Svatý v rámci jednoho souvětí. Strana, již autor textu zastává, se tak ocitá v těsné blízkosti zmíněných církevních autorit (apoštolové, světci), naopak Michal a jeho následovníci zůstávají osamoceni se svými vlastními výmysly a s bláhovým spoléháním se na vlastní rozum. Za povšimnutí též stojí, že se zde klade dưraz na pomyslnou hranici, resp. mez - recipientovi se tak podsouvá jasně strukturovaný pohled na náboženský život. Pisatel vzápětí připojuje i koncept ,výšky', aby zdůraznil společensko-náboženskou hierarchii, jde tedy o vizuální pomůcku: „[K]něz Michal s svou rotou přiliš vysoce smyslí, víc než jest potřebí pravíce, že sou již pravou a jistou cestu nalezli do nebe“ (IBID.: 124). Cesta ,do výšky' se prolíná s konceptem cesty jako pěšiny, která může vést ke spasení, nebo naopak k zatracení. Zde se autor textu dokonce opírá o slova Ducha svatého („Duch Svatý proti nim dí..."). Svedení na scestí od členů Jednoty bratrské se má dít „skrze jich sladké a upřímé řeči“ (IBID.: 124-125). Je-li v určité pasáži textu Jednotě vytýkána nekompetentnost a neučenost, zde se naopak pracuje s do jisté míry protichůdnou schopností protivníka ošálit pěknými slovy mnohé věřící. Ukazuje se tak silný důraz na využití argumentu na úkor mimotextové reality. ,Sladkost'v každém případě může implicitně vést $\mathrm{k}$ dalšímu odkazu na chut', a to je jed, jímž může protivník metaforicky otrávit každého, kdo jej poslouchá.

V závěrečné pasáži tohoto listu autor vyzývá Jednotu, aby „nechajíce rozbrojův a výtržek všetečných stáli v jednotě víry a v poslušenství církve svaté“ (IBID.: 125). Je zajímavé, že velmi podobnými slovy vyzývali zástupci basilejského koncilu kališníky, a to i ty konzervativní, aby opustili bludné myšlenky a vrátili se do lůna církve. Martin Lupáč tehdy odmítl podřídit se požadavkům papeže i koncilu na základě Písma, které podle něj stojí autoritou nejvýše. Pro latinskou církev však „[Písmo] lze považovat za spolehlivou rozhodčí autoritu jen v případě, že jej interpretujeme prizmatem církevních doktrín, které jsou z Písma odvozeny. Církev je prvotní, Písmo druhotné“ (FUDGE 2017: 278).

Pozoruhodná situace z hlediska pojetí autority ovšem nastává již ve vztahu k listu Jana Rokycany „proti pikhartóm“ (List mistra Rokycány in AJB 1 1915: 488). Autor (podle titulu by mělo jít právě o Rokycanu) promlouvá z nadřazené pozice duchovního, přestože jako arcibiskup, jak byl v českých zemích kališníky nazýván, nebyl papežem uznán a v evropském kontextu vystupoval spíše z pozice heretika, který se musí obhájit. Ve zmíněném listu bychom však nic $z$ této kontroverze nenalezli. Reflektuje se zde Rokycanova zkušenost s kázáním 
k laickým posluchačům. Přestože je text nazván jako list, označili bychom jej dnešním měřítkem spíše jako traktát, i když syntakticky připomíná právě styl Rokycanovy postily ${ }^{6}$. Pisatel patrně počítá s tím, že text bude recipovat široký okruh čtenářů/posluchačů, nejspíš však sdělení přizpůsobil právě i „pikartům“, o jejichž vzdělání asi neměl valné mínění: „[K] tomuto vás napomínám, abyšte věřili a drželi, že u velebné svátosti jest celý Kristus, pravý Buoh a pravý člověk v svém vlastním přirození a podstatě“ (List mistra Rokycány in AJB 1 1915: 489). Dotýká se zde zásadní příčiny rozepří jak mezi utrakvisty a římskou církví, tak mezi utrakvistickými frakcemi: transsubstanciace.

$\mathrm{V}$ listech z téže sbírky psaných bratrskými autory nalezneme právě i reflexi nálepky pikart (viz například Třetí list mistru Rokycanovi z prvního svazku Aktů Jednoty bratrské). Takto si pisatel stěžuje na poškození pověsti Jednoty, jež dává za vinu mimo jiné Rokycanovi: „A kde by dva anebo tří mluvili o dobrém, hned dějí, že sú pikharti, neb pikharty po tom nejlépe znají, že s nimi nehřeší a že nemají obyčeje jako oni přísahati, láti, oplzle mluviti a lháti a že nechtí se mstíti, ani cizího bráti“ (IBID.). Autor zde pracuje s dobovým pojetím výrazu pikart či pikhart - odpovídá mu širší definice coby „vyznavače radikální reformace“ nebo „bludaře“ (viz „Pikhart“ in VOKABULÁ̌̌). Jednotě bratrské tato nálepka slouží k implicitní sebedefinici a obhájení vlastního jednání; jsou-li označeni touto nálepkou, s níž se pojí určitá charakteristika, dá se tím pádem výše uvedený popis vztáhnout i na ně. Nepřímo tak autor prohlašuje, že i členy Jednoty bratrské lze označit jako ty, kteří jsou čistí, neberou boží jméno nadarmo, nelžou, nekradou atd. V dalším listu Rokycanovi zase čteme, že podle nepřátel jsou bratři „Samaritáni, svuodce bludní, kacíři“ (Čtvrtý list mistru Rokycanovi in AJB 1 1915: 48). Podobná charakteristika však podporuje bratrskou snahu vykreslit svět jako antitetický, kde je skutečná podoba věcí opačná, než jak se lidem běžně zdá. Antiteze odpovídá interpretaci pozemské a nebeské církve, jak ilustruje již např́klad traktát Tabule veteris et novi coloris Mikuláše z Drážd'an ${ }^{7}$ ze 14. století. Pisatel (či pisatelé) listů Jednoty bratrské používají antitetické nahlížení nejen $\mathrm{k}$ tomu, aby popsali chod světa, ale také jako účinný nástroj k přesvědčení čtenáře. Figuruje zde metafora tmy a slepoty:

„Proč jest to, že tak mluví, že ten, ktož ukazuje víru dobrú skrze skutky dobré a život ctnostný, že jí nemá, a kdož ukazuje nevěru skrze život hřiechu a smrti poddaný, že má víru dobrú? To jest proto,

6) Rokycanova Postila byla sestavena po roce 1462, nejstarší dochovaná kopie vznikla až po jeho smrti.

7) Dílo se dochovalo i v českém překladu. V moderní edici vyšlo roku 2016 pod názvem Tabule staré a nové barvy Mikuláše z Drážd'an ve staročeském prekladu. 
že zlost oslepila oči jich, aby vidúce neviděli a slyšíce neslyšeli“ (Čtvrtý list mistru Rokycanovi in AJB 1 1915: 23).

Spíše rétorickou otázku následuje výmluvná odpověd': autor předkládá jasně stanovený pohled na svět a nabízí vysvětlení.

Pozice Jednoty v textu však nezůstává neměnná; nacházíme zde dva základní způsoby, jakými jsou bratří ve svých listech vykresleni. Typicky pisatel charakterizuje bratry jako pokorné, tiché a chudé, rovněž vystavované utrpení a utlačované - vzniká tak paralela s Ježíšovými učedníky a ranými křest́any:

„Ale z toho se radujem, že se na nás ty věci shledávají, kteréž psány sou o posledních křestanech věrných tak, jakož sami muožte tomu rozuměti, [...] kteraké protivenství trpíme pro spravedlnost od světského lidu i duchovnieho, kterak proti nám zlostně povstávají a nenávidí darmo“ (IBID.: 53).

Autor $\mathrm{z}$ řad Jednoty tak dává najevo, že veškeré příkoří snášejí s radostí, nebot' si tím získávají místo po boží pravici - utrpení jim napomáhá ke spáse. Zdá se, že bratří jsou téměř hrdí na špatnou pověst, kterou zapříčinil i Jan Rokycana: jsou kvůli němu „lidé ponížení a zlú pověstí ohyždění“ (List všem vůbec in AJB 1 1915: 218).

Polemický protivník ovšem optikou Jednoty ponese za své jednání následky. V listech Akti̊ Jednoty bratrské bratrští autoři odkazují k Novému zákonu mnohem častěji než ke Starému, zde však využívají jednoduchou paralelu s Izraelity. Moc světská i duchovní, jež podrobuje Jednotu př́íkoří, na sebe uvalí boží hněv, jak můžeme číst v „Listu všem vůbec“ $\mathrm{z}$ roku 1468:

„Protož prosíme pro zasloužení pána Krista a pro lásku Ducha Svatého, abyšte nás mimo toto poddánie, k kterémuž se ohlašujem podlé zprávy apoštolské, nenutili dále trápiece, neb to Vašim Milostem osvědčujem před Pánem Bohem, [...] pomstu časnú i věčnú na se shromáždíte, jakožto někdy se přiházelo králuom Izdrahelským“ (IBID.: 264).

Opět zde tedy můžeme identifikovat případ deviace od většinového náhledu na společenskou hierarchii, považuje-li se Jednota za vykonavatele boží vưle. Deviantní jednání však kontrastuje s očividně podřízenou pozicí, kterou se bratři snaží dávat najevo např́iklad v listu „Panu Albrechtovi““8. Pomocí kompenzační strategie si vytváří prostor pro vyjádření - snaží se obhájit jeho legitimitu:

8) Jde o Albrechta Kostku z Postupic, původně utrakvistu, jemuž bratří adresovali zmíněný list po jeho konverzi ke katolictví. 
„[P]rosímet: Strpte nás dobrotivě v tom, což píšem, neb máme za to, když vám dal pán Buoh známost dokonále těch věcí, v kterých se ustavujem, nemohli byšte nikoli toho za zlé míti, neb jest z Boha pravda pošla..." (Panu Albrechtovi in AJB 1 1915: 198).

Pisatel nerozporuje oprávněnost adresátovy nadřazenosti. Ukazuje se zde totiž mnohem pragmatičtější úhel pohledu na činnost Jednoty. Bratří prohlašují, že bude-li jim dán prostor pro vlastní obhajobu, chtěli by „prositi Královy Milosti i pánuov, aby nás strpěli v tomto království, jakož snášejí v království Polském neb Uherském Rusy, Ráce i také bratří moldavské i jiné, abychom sloužili pánu Bohu pod panováním jich“ (IBID.: 200). Akcentuje se tu pokora, ochota ke smíru a světská podřízenost. Bratří se tak snaží přesvědčit Albrechta Kostku z Postupic, aby jim nadále dovolil působit na svém panství. Dá se též předpokládat, že Jednota bratrská touží po klidnějším soužití. Ilustruje to např́iklad smutný osud kněze, jež zmiňují v tomtéž textu:

„I druhý kněz, Štefan, také byl povolil i poddával se tak, což bychom koli při něm znamenali scestného při víře pána Krista proti zákonu božiemu a první církvi, že chce rád opraviti; a v tom pak času upálen v Viedni“ (IBID.: 202).

Násilné jednání se tedy nejeví být žádoucím; přirozená snaha vyhnout se nepř́jemným, ba nebezpečným situacím zde má přednost před poněkud neurčitou touhou zasloužit si místo po boží pravici díky utrpení.

Dá se tedy říci, že hereze v listech, které si Jednota bratrská vyměňovala s náboženskými protivníky různé afiliace, neslouží pouze jako formální nálepka, ale napomáhá odpůrcům jasně kategorizovat osoby s nežádoucím (deviantním) jednáním a pro zastánce radikálnějších postojů představuje na jednu stranu přízvisko, na které mohou být hrdi, a na stranu druhou označení, jehož sociální dopad je nutné mírnit. I z tohoto důvodu se bratrští autoři snaží upravit obraz sebe sama v očích veřejnosti - proto, aby pomohli na cestě ke spáse více lidem, ale též $\mathrm{z}$ toho důvodu, aby mohli působit v klidu a bezpečí a nemuseli čelit př́ikořím plynoucím $\mathrm{z}$ jejich nelichotivého sociálního statusu bludařů, pikartů a církevních odrodilců. 


\section{PRAMENY}

Akty Jednoty bratrské. Sv. I.

1915 Ed. Jaroslav Bidlo. Brno: Matice moravská. Dostupné z: http://147.231.53.91/src/index.php?s=v\&cat $=198$ bbookid $=836$ [cit. 12. 8. 2021]

Čtvrtý list k mistru Rokycanovi, počet vydávající z víry a z naděje i z jiných věcí křestananských, zvlášt o svátostech (16-54)

Panu Albrechtovi (197-205)

List všem vưbec (264-267)

List mistra Rokycány proti pikhartom. Rozeslán po městech věrných a zapsán na rathouze Pražském Starého Města (488-491)

Akty Jednoty bratrské. Sv. II.

1923 Ed. Jaroslav Bidlo. Brno: Moravská akciová knihtiskárna. Dostupné z: http://147.231.53.91/src/index.php?s=v\&cat=19\&bookid $=834$ [cit. 12. 8. 2021]

Psaní mistrův Pražských proti Bratřím ku potvrzení listu Rokycánova proti Bratřím psaného (119-131)

\section{LITERATURA}

BIDLO, Jaroslav

1923 „Látka druhého svazku Aktů“, in: Akty Jednoty bratrské. Sv. 2. 1. vyd. Brno: Matice moravská, s. 11-91

CLINARD, Marshall a Robert F. MEIER

2008 Sociology of deviant behavior. 13. vyd. Belmont, CA: Thomson/Wadsworth, ISBN 978-0495093350

DEANE, Jennifer

2011 A history of medieval heresy and inquisition. 1. vyd. Lanham: Rowman \& Littlefield, ISBN 9780742555761

FUDGE, Thomas

2005 "Seduced by theologians: Aeneas Sylvius and the hussite heretics", in: Heresy in transition. Transforming ideas of heresy in medieval and early modern Europe. Ian Hunter, John Christian Laursen a Cary J. Nederman, eds. Burlington, Ashgate Publishing Company, s. 89-101. ISBN 027546-5428-1

HUNTER, Ian, John Christian LAURSEN a Cary J. Nederman

2005 "Introduction", in: Heresy in transition. Transforming ideas of heresy in medieval and early modern Europe. Ian Hunter, John Christian Laursen a Cary J. Nederman, eds. Burlington: Ashgate Publishing Company, s. 1-8. ISBN 027546-5428-1

\section{ROGGE, Jörg a Kristina MÜLLER-BONGARD}

2016 "Recounting deviance. Forms and practices of presenting divergent behaviour in the late middle ages and early modern period - an introduction", in: Mainzer Historische Kulturwissenschaften, 34. Bielefeld: transcript Verlag. E-kniha. Dostupné z: https://eds.b.ebscohost.com/eds/ebookviewer/ebook/bmxlYmtfXzEyOTUz- 
Michaela Vašíčková

Hereze v listech rané Jednoty bratrské

MzdfXOFO0?sid=1079478b-546d-44f0-b827c295138bf7f9@sessionmgr120\&vid=2\&format=EB\&rid=1 [cit. 12. 8. 2021]

SUCHÁNEK, Drahomír a Václav DRŠKA

2013 Církevní dějiny. Antika a středověk. Praha: Grada, ISBN 978-80-247-3719-5

(1) Vokabulár̆ webový: webové hnizdo pramenů k poznání historické češtiny [online]. Praha: Ústav pro jazyk český AV ČR, v. v. i., oddělení vývoje jazyka. (C) 2006-2021. Verze dat 1.1 .15 [cit. 12. 8. 2021]. Dostupné z: https:// vokabular.ujc.cas.cz

Mgr. Michaela Vašičková, 399851@mail.muni.cz, Ústav české literatury, Filozofická fakulta, Masarykova universita, Brno, Česká republika / Department of Czech Literature, Faculty of Arts, Masaryk University, Brno, Czech Republic 